\title{
Lanthanide(III) Chelates of DTPA Bis(amide) Glycoconjugates: Potential Imaging Agents Targeted at the Asyaloglycoprotein Receptor
}

\author{
Paula Baía, ${ }^{[a]}$ João P. André, *[a] Carlos F. G. C. Geraldes, ${ }^{[b]}$ José A. Martins, ${ }^{*[a]}$ \\ André E. Merbach, ${ }^{[c]}$ and Éva Tóth ${ }^{[c]}$
}

Keywords: Chelates / Contrast agents / Lanthanides / Glycoconjugates / Receptors

The synthesis and characterisation of a new class of DTPA bis(amide) linked glycoconjugates of different sugars [lactose (Lac) and galactose (Gal)] and valencies (di and tetra) and their $\mathrm{Ln}^{\mathrm{III}}$ complexes is reported. The ${ }^{1} \mathrm{H}$ NMR spectra of the $\mathrm{Sm}^{\mathrm{III}}$ and $\mathrm{Eu}^{\mathrm{III}}$ complexes of $\mathrm{DTPAGal}_{2}, \mathrm{DTPAGal}_{4}$, and DTPALac 2 , obtained between 7 and $80{ }^{\circ} \mathrm{C}$, indicate that several of the four possible diastereoisomeric pairs of structures resulting from the chirality of the three bound DTPA nitrogen atoms are present in solution, with different relative populations. The dynamic effects of racemisation of the central nitrogen atom in the NMR spectra show that this process is fast at $60{ }^{\circ} \mathrm{C}$ for the $\mathrm{Sm}^{\mathrm{III}}$ complexes and slow at $7^{\circ} \mathrm{C}$ for the $\mathrm{Eu}^{\mathrm{III}}$ complexes. The in vitro $r_{1}$ nuclear magnetic relaxation dis- persion (NMRD) of the water protons of the Gd ${ }^{\mathrm{III}}$-DTPA bis(amide) glycoconjugate containing two lactosyl moieties

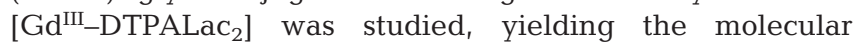
parameters that govern its relaxivity. Its $r_{1}$ value, at $25{ }^{\circ} \mathrm{C}$ and $20 \mathrm{MHz}$, is $13 \%$ higher than that reported for $\mathrm{Gd}^{\mathrm{III}}$ chelates of lower molecular weight DTPA bis(amides), such as DTPABMA, consistent with a five times larger $\tau_{\mathrm{R}}$ value. The water exchange rate, $k_{\text {ex }}$, and the electron spin relaxation parameters of the $\mathrm{Gd}^{\mathrm{III}}-\mathrm{DTPALac}{ }_{2}$ complex are within the usual

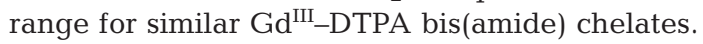

() Wiley-VCH Verlag GmbH \& Co. KGaA, 69451 Weinheim, Germany, 2005)

\section{Introduction}

Magnetic resonance imaging (MRI) is one of the fastest growing techniques in medical diagnosis due to the excellent spatial resolution and contrast, in particular for soft tissues. The image contrast is based mainly on the differences of water proton longitudinal $\left(1 / T_{1}\right)$ and transversal $\left(1 / T_{2}\right)$ relaxation rates in different tissues. This contrast can be enhanced with the administration, prior to the scan, of paramagnetic contrast agents (CAs), usually $\mathrm{Gd}^{\mathrm{III}}\left(4 \mathrm{f}^{7}\right)$ complexes, ${ }^{[1,2]}$ which accelerate the proton relaxation processes in the surrounding water through dipolar interactions between the unpaired electron spin of the metal ion and the proton nuclei of the water molecules. The $\mathrm{Gd}^{\mathrm{III}}$ chelate of DTPA [DTPA $=3,6,9$-tris(carboxymethyl)-3,6,9-triazaundecane-1,11-dioic acid)], [Gd(DTPA) $\left.\left(\mathrm{H}_{2} \mathrm{O}\right)\right]^{2-}$, was the first

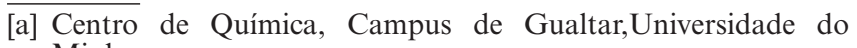
Minho,

4710-057 Braga, Portugal

Fax: +351-253-678-983

E-mail: jandre@quimica.uminho.pt jmartins@quimica.uminho.pt

[b] Departamento de Bioquímica, Centro de Espectroscopia RMN e Centro de Neurociências e Biologia Celular, Universidade de Coimbra,

Coimbra, Portugal

[c] Laboratoire de Chimie Inorganique et Bioinorganique, École Polytechnique Fédérale de Lausanne Switzerland

Supporting information for this article is available on the WWW under http://www.eurjic.org or from the author. contrast agent (CA) used for human MRI, under the name of Magnevist ${ }^{\mathbb{B}} \cdot{ }^{[3]}$ Its success stimulated further studies on modifications of its structure, leading, amongst others, to the neutral derivative $\left[\mathrm{Gd}(\mathrm{DTPA}-\mathrm{BMA})\left(\mathrm{H}_{2} \mathrm{O}\right)\right]$ [Omni$\operatorname{scan}^{\circledR}$; DTPA-BMA = diethylenetriaminepentaacetic acid $N, N^{\prime \prime}$-bis(methylamide)], in which two carboxylate groups have been converted into amide functions. ${ }^{[4]}$ These, as well as other hydrophilic linear or macrocyclic $\mathrm{Gd}^{\mathrm{III}}$ chelates of similar dimensions and simplicity, once injected, rapidly diffuse from the intravascular space into the interstitial space, but do not enter the intracellular space. Their rapid renal elimination produces a rapid decrease in tissue Gd concentration. ${ }^{[5]}$

Although much used, for example in neuropathological conditions, which are often associated with disruption of the blood brain barrier (BBB) or altered capillary permeability, these extracellular fluid (ECF) CAs also have inherent disadvantages due to their lack of biospecificity, low relaxivities, and poor uptake elsewhere in the body. Their rapid diffusion from the vasculature limits their uses as blood pool agents, for example in estimates of blood flow and perfusion. For such applications, several formulations of DTPA conjugates have been tested, both through covalent binding of the $\mathrm{Gd}^{\mathrm{III}}$ chelate to suitable macromolecules (albumin, ${ }^{[6]}$ dextran, ${ }^{[7]}$ polylysine, ${ }^{[8]}$ dendrimers ${ }^{[9]}$ ) or noncovalent binding to HSA (human serum albumin), ${ }^{[10]}$ for example the Gd-DTPA derivative MS-325. ${ }^{[1]}$ The search for new ligands with high tissue and/or organ specificity 
started with hepatobiliary CAs, such as $\mathrm{Gd}^{\mathrm{III}}$ chelates, which are hepatocyte-specific and are excreted through the hepatobiliary system. Amongst these are $\mathrm{Gd}^{\mathrm{III}}$ chelates of DTPA-derived ligands bearing various lipophilic substituent groups which promote specific carrier-mediated uptake into the hepatocytes, such as benzyloxymethyl in [Gd$($ BOPTA $\left.)\left(\mathrm{H}_{2} \mathrm{O}\right)\right]^{2-} \quad[$ BOPTA $=$ 4-carboxy-5,8,11-tris(carboxymethyl)-1-phenyl-2-oxa-5,8,11-triazatridecan-13oic acid $]^{[12]}$ and ethoxybenzyl in [Gd(EOB-DPTA $\left.)\left(\mathrm{H}_{2} \mathrm{O}\right)\right]^{2-}$ [EOB-DTPA $=(S)-N-\{2-[$ bis (carboxymethyl)amino]-3-(4ethoxyphenyl)propyl $\}-N$ - $\{2$-[bis(carboxymethyl)amino]ethyl\} glycine]. ${ }^{[13]}$ Liposomes can also be efficient carriers to deliver $\mathrm{Gd}^{\mathrm{III}}$-based CAs to the liver and spleen and hence enhance their MRI image contrast. The amphiphilic Gd(DTPA)-stearylamide, for example, is incorporated into the phospholipid lamella of egg lecithin and cholesterol liposomes. ${ }^{[14]}$
The hepatocyte cells on liver express a tissue-specific lectin (hepatic lectin) that recognizes terminal $\beta$-galactosyl residues on desialylated glycoproteins - the asialoglycoprotein receptor (ASGPR). ${ }^{[15]}$ Liver targeting has been successfully achieved through conjugation of pharmaceutical agents to galactose/lactose. ${ }^{[16]}$ Moreover, a multivalence effect has been demonstrated on the liver uptake of glycoconjugates (tetra $>$ tri $>$ di $>$ mono). ${ }^{[17]}$ Several agents that rely on macromolecular bioconjugates and on polymer scaffolds have been described for hepatic imaging through the targeting of the ASGPR. ${ }^{[18-25]}$ These agents have the drawback of being inherently polydisperse and ill characterised.

In a previous paper we reported the synthesis and physicochemical characterisation of a new class of multivalent glycoconjugates - $\mathrm{Ln}^{\mathrm{III}}$ chelates of the tetraazatetracarboxylate chelator DOTA conjugated to glycodendrimeric moieties [DOTA $=1,4,7,10$-tetrakis(carboxymethyl)-
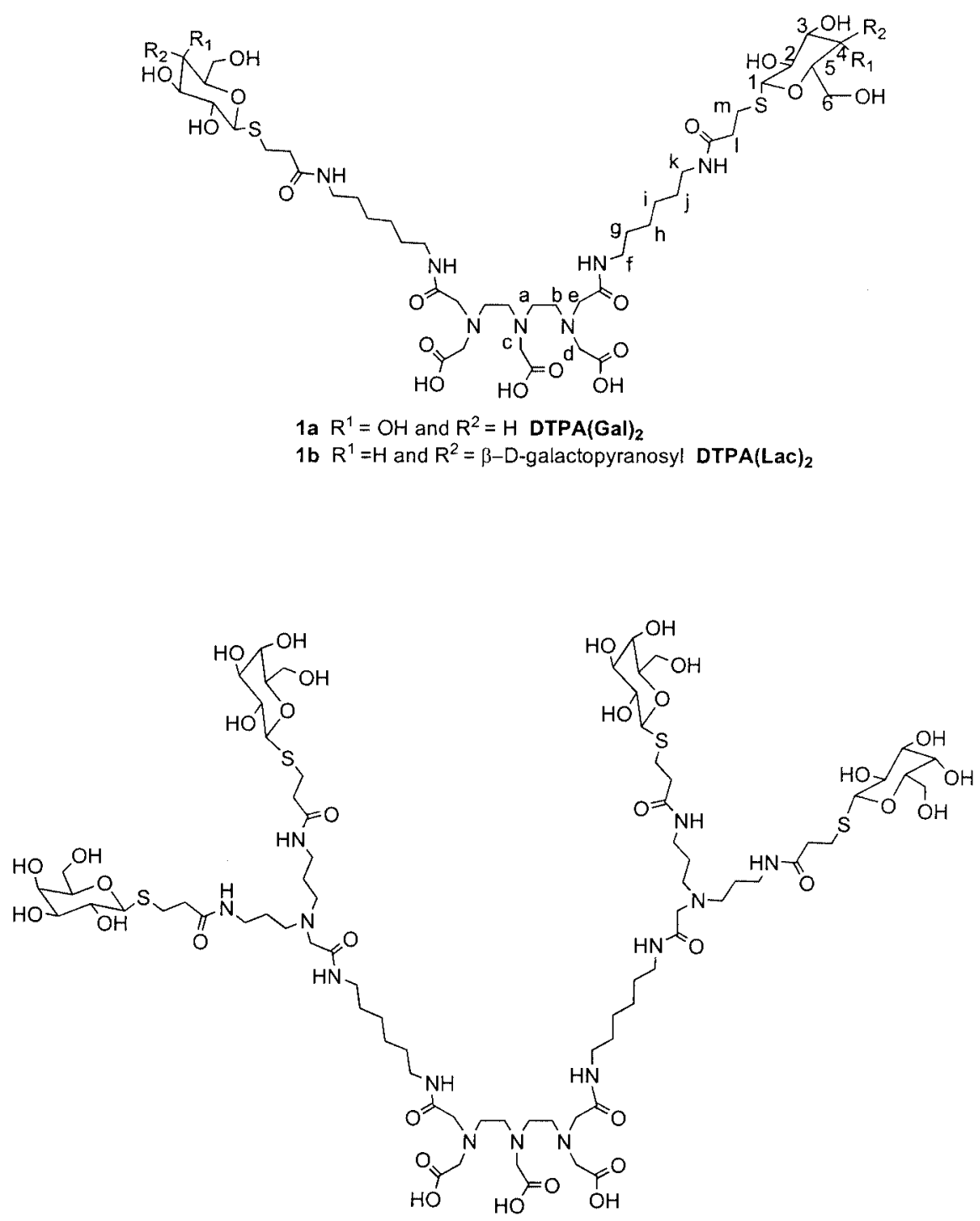

2 DTPA $(\mathrm{Gal})_{4}$

Figure 1. Structures of the DPTA bis(amide) glycoconjugates (the labelling of the protons for spectral assignments is shown). 
1,4,7,10-tetraazacyclododecane]. ${ }^{[26]}$ Previous to our work, only a class of low molecular weight and well-characterised galacto/mannopyranosyl conjugates of DOTA-like chelators had been described for potential MRI and scintigraphic applications. ${ }^{[27]}$ These monovalent $\mathrm{Gd}^{\mathrm{III}}$-glycoconjugates are responsive contrast agents activated by galactosidase/mannosidase-mediated hydrolysis. ${ }^{[28]}$ In this paper we report the synthesis and characterisation of (thio)glycoconjugates of the linear chelator DTPA, namely the DTPA bis(amides) 1 and $\mathbf{2}$ with different terminal sugar residues galactose (Gal) and lactose ( $\mathrm{Lac}$ ) - and different valences ( 2 and 4; Figure 1). The thioglycosides are galactosidaseresistant ligands that probe a conformational space and display biological activities very similar to that of their $O$ linked natural counterparts, thus ensuring an increased metabolic stability in vivo. ${ }^{[29]}$ The physicochemical characterisation of some of their $\mathrm{Ln}^{\mathrm{III}}$ complexes in aqueous solution by ${ }^{1} \mathrm{H}$ NMR and water ${ }^{1} \mathrm{H}$ NMRD studies is also described. The proton relaxivity of the $\mathrm{Gd}^{\mathrm{III}}$ chelates describes the efficiency of the magnetic dipolar coupling between the water proton nuclei and the paramagnetic metal ion, therefore it is a direct measure of the efficacy of the chelate as a CA.

\section{Results and Discussion}

\section{Synthesis of the Ligands}

The synthesis of the DTPA bis(amides) 1 and 2 (Figure 1) was undertaken through a well-established route consisting of the derivatisation of the commercially available DTPA bis(anhydride) with amine-functionalised blocks. Two different types of amine-functionalised sugar blocks were prepared: a monovalent block 5 (Scheme 1) and a divalent glycodendrimer block 9 (Scheme 2). ${ }^{[26,31]}$ The standard DCC/HOBT coupling procedure was found to be successful for preparing the fully protected amino-functionalised sugar blocks. These compounds were deprotected with TFA/ $\mathrm{CH}_{2} \mathrm{Cl}_{2}$ to afford the terminal amines $\mathbf{6}$ and $\mathbf{1 0}$ as their TFA salts.

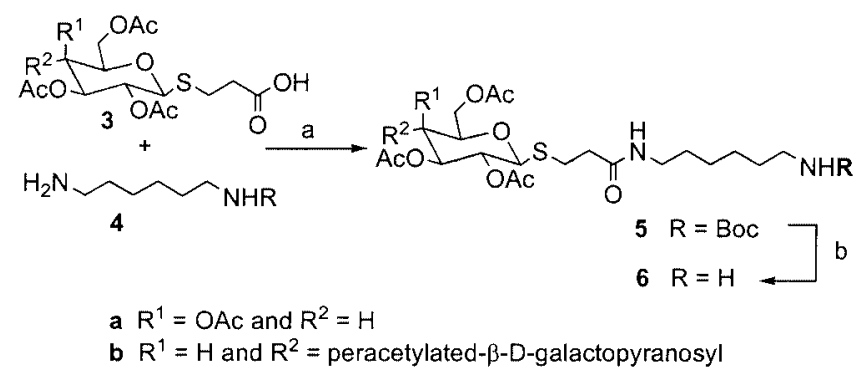

Scheme 1. a) DCC/HBT, DCM; b) TFA/DCM (1:3).

In order to ensure the formation of the required bis(amides), the amino-functionalised blocks $\mathbf{6}$ and $\mathbf{1 0}$ were used in a slight excess, over two mol-equiv. in relation to the DTPA bis(anhydride) block (Scheme 3). The intermediate sugar-protected bis(amides) were carried through and deprotected with $\mathrm{KOH}$ in methanol/water to give the final compounds $\mathbf{1}$ and $\mathbf{2}$ in reasonable yields.

\section{NMR Studies of the $\mathrm{Ln}^{\mathrm{III}}$ Glycoconjugates}

The ${ }^{1} \mathrm{H}$ NMR spectra of the 1:1 diamagnetic ( $\left.\mathrm{La}^{\mathrm{III}}\right)$ and paramagnetic $\left(\mathrm{Sm}^{\mathrm{III}}\right.$ and $\left.\mathrm{Eu}^{\mathrm{III}}\right)$ complexes with the ligands DTPAGal $_{2}$, DTPALac $_{2}$ and DTPAGal ${ }_{4}$ were obtained in $\mathrm{D}_{2} \mathrm{O}$ at $\mathrm{pH}=7.5$ as a function of temperature $(7,25,40$, 60 and $80^{\circ} \mathrm{C}$; see Figures $2-4$ for some typical spectra). The spectra of the $\mathrm{La}^{\mathrm{III}}$ complexes show many identical resonances to those of the corresponding free ligand at the same $\mathrm{pH}$ for the protons of the sugar rings and bridging arms (Figure 2). However, the protons of the DTPA moiety, or next to it, such as $\mathrm{CH}_{2}(\mathrm{f})$, give more complex resonances as a result of ion coordination: a multiplet at $\delta=2.92 \mathrm{ppm}$ for $\mathrm{CH}_{2}(\mathrm{f})$, multiplets at $\delta=2.95,2.78,2.68$ and $2.45 \mathrm{ppm}$ for the backbone $\mathrm{NCH}_{2} \mathrm{CH}_{2} \mathrm{~N}$ protons, and a series of partially

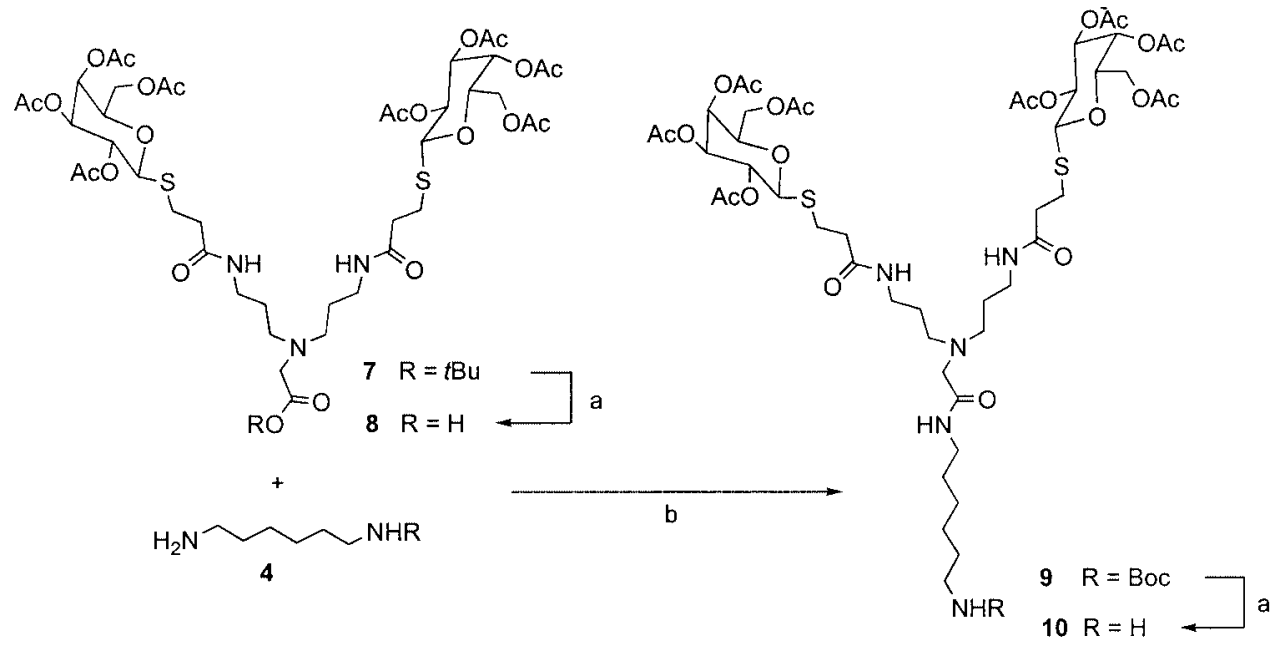

Scheme 2. a) TFA/DCM (1:3); b) i. DIPEA/DCM; ii. DCC/HBT, DCM. 


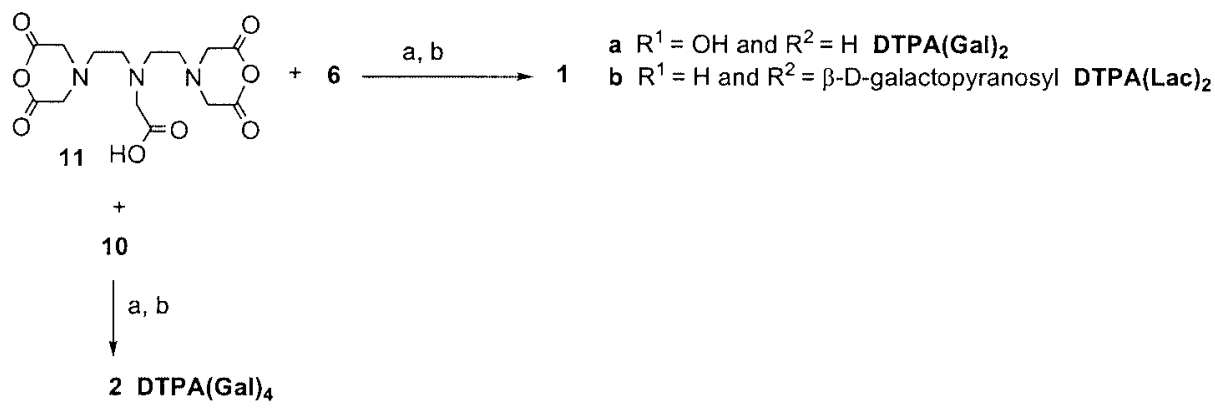

Scheme 3. a) i. DIPEA/DCM; ii. DMF/Py; b) i. $\mathrm{KOH} / \mathrm{EtOH}$; ii. Amberlyst 15 , elution with $\mathrm{NH}_{3}$.

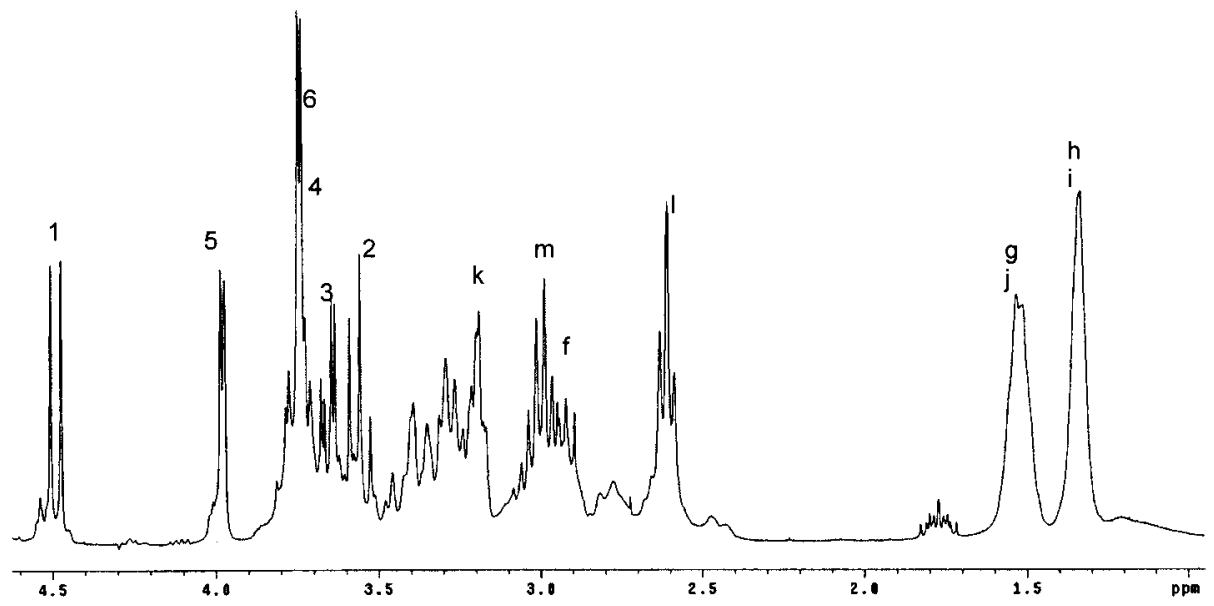

Figure 2. ${ }^{1} \mathrm{H}$ NMR spectrum of $\mathrm{La}^{\mathrm{III}}-\mathrm{DTPAGal}{ }_{2}$ glycoconjugate in $\mathrm{D}_{2} \mathrm{O}, \mathrm{pH}=7.0, T=25^{\circ} \mathrm{C}$.

overlapping $\mathrm{AB}$ patterns in the $\delta=3.2-3.5 \mathrm{ppm}$ region for the $\mathrm{CH}_{2}$ protons of the acetate and amide arms, quite similar to what has been described for [La(DTPA) $]^{2-}$ and other La[DTPA bis(amides)]. ${ }^{[32-36]}$ For the $\mathrm{Sm}^{\mathrm{III}}$ and $\mathrm{Eu}^{\mathrm{III}}$ complexes, the ligand protons far from the paramagnetic centre, at the sugar rings (H-1-H-6) and at bridging arms $\left[\mathrm{CH}_{2}(\mathrm{~g}-\right.$ $\mathrm{m})$ ], show very small paramagnetic broadenings and their shifts are easily assigned (see Figure 3 ). ${ }^{[36]}$ The strongly shifted and broadened proton resonances of the side chain $\mathrm{CH}_{2}(\mathrm{f})$ and the $\mathrm{CH}_{2}$ of the DTPA amide moiety could not be specifically assigned, despite showing some features similar to the corresponding paramagnetic complexes of the parent DTPA and some DTPA bis(amide) ligands. ${ }^{[36-42]}$

For the $\mathrm{Sm}^{\mathrm{III}}$ complexes, most of these strongly shifted resonances are too broad to be detected at $25^{\circ} \mathrm{C}$ but sharpen at higher temperatures. At $60^{\circ} \mathrm{C}$ some appear in the diamagnetic region $(\delta=5.8-4.8$ and $3.3-0.6 \mathrm{ppm})$ and seven are shifted to the low frequency $\delta=0.1$ to $-1.4 \mathrm{ppm}$ region (Figure 3). In contrast, in the $\mathrm{Eu}^{\mathrm{III}}$ complexes the shifted resonances are quite sharp at low temperature $\left(7^{\circ} \mathrm{C}\right.$, see Figure 4): ten resonances are observed in the high-frequency $\delta=35-15 \mathrm{ppm}$ region, about eight in the $\delta=10$ $5 \mathrm{ppm}$ region and about twenty in the $\delta=-3$ to $-18 \mathrm{ppm}$ region. These are totally broadened when the temperature is increased to $25^{\circ} \mathrm{C}$, but at $60{ }^{\circ} \mathrm{C}$ some sharp, less shifted resonances reappear, for example in the $\delta=6.2$ to $-10.2 \mathrm{ppm}$ region (data not shown).
In $\mathrm{Ln}^{\mathrm{III}}$ complexes of DTPA bis(amides) with non-chiral centres in the side chains, with a cation nine-coordinate by one inner-sphere water molecule and eight ligand donor atoms, all three bound nitrogen atoms are chiral and four diastereoisomeric pairs of enantiomers are possible, leading to a maximum of eight NMR signals for each group of magnetically equivalent protons. ${ }^{[36,40]}$ This type of complex can undergo two distinct isomerisation processes in solution. The racemisation of the terminal $\mathrm{N}$ atoms, involving decoordination-inversion-coordination of the $\mathrm{N}$ atoms and the neighbouring acetate groups, has a high energy barrier. A lower energy process involves racemisation of the central nitrogen atom by interconversion between the two possible conformations of the ethylene bridges, which results in the magnetic averaging of the two halves of the complex around the central glycinate group of DTPA and reduces by half the number of observed resonances. ${ }^{[36,40]}$ This is the dynamic process observed in the present study, which is fast at $60^{\circ} \mathrm{C}$ for the $\mathrm{Sm}{ }^{\mathrm{III}}$ complexes and slow at $7^{\circ} \mathrm{C}$ for the $\mathrm{Eu}^{\mathrm{III}}$ complexes due to the much larger dipolar shifts induced by $\mathrm{Eu}^{\mathrm{III}}$ relative to $\mathrm{Sm}^{\mathrm{III}}$.

The total number of strongly shifted proton resonances observed for the $\mathrm{Sm}^{\mathrm{III}}$ and $\mathrm{Eu}^{\mathrm{III}}$ complexes studied here, although they could not be assigned, leads to the unambiguous conclusion that they occur as more than one isomer in solution. A comparison of the ${ }^{1} \mathrm{H}$ NMR spectra with those of corresponding DTPA complexes ${ }^{[33,39]}$ suggests that 


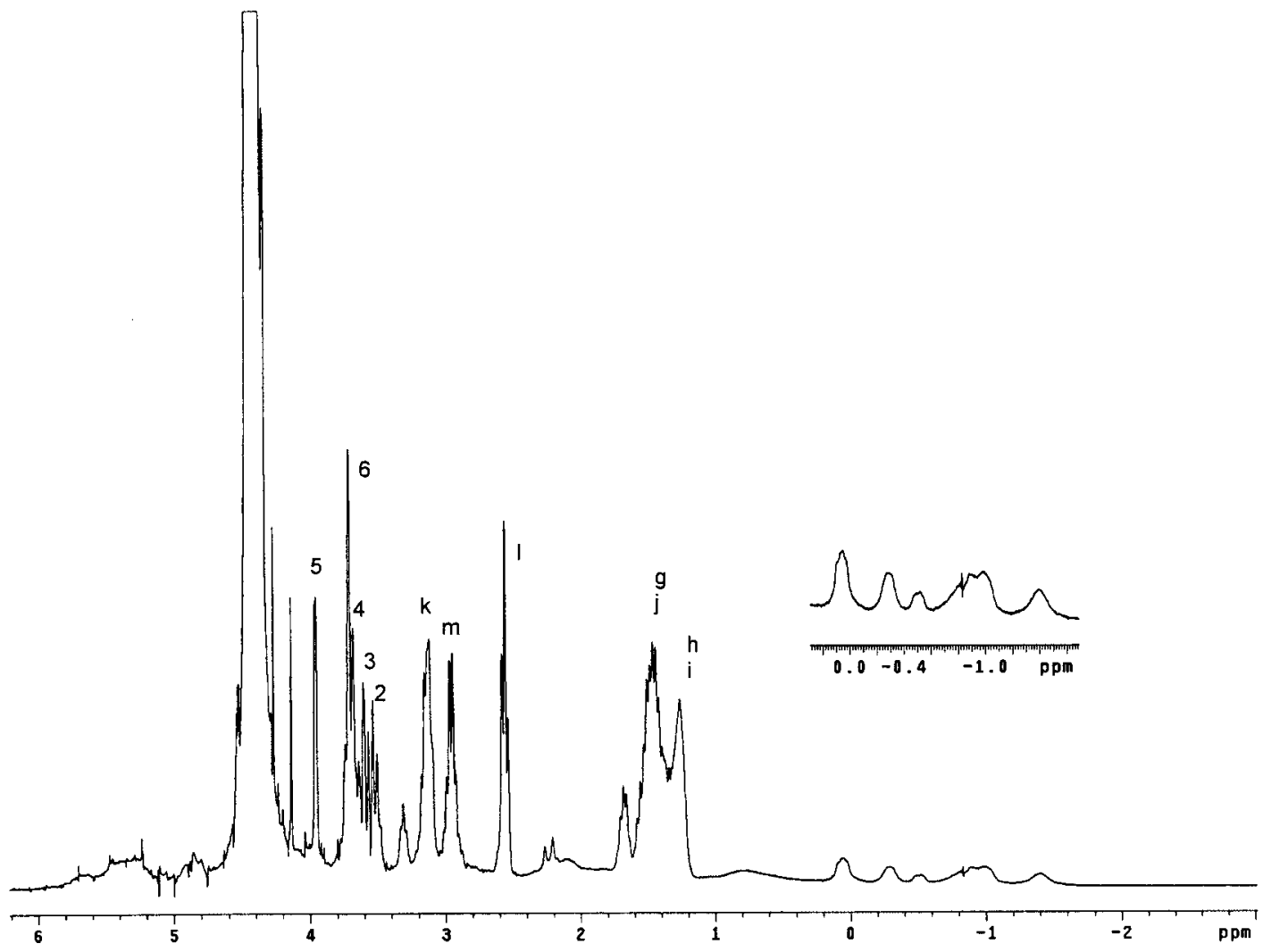

Figure 3. ${ }^{1} \mathrm{H}$ NMR spectrum of $\mathrm{Sm}^{\mathrm{III}}-\mathrm{DTPAGal}{ }_{2}$ glycoconjugate in $\mathrm{D}_{2} \mathrm{O}, \mathrm{pH}=7.0, T=60{ }^{\circ} \mathrm{C}$.

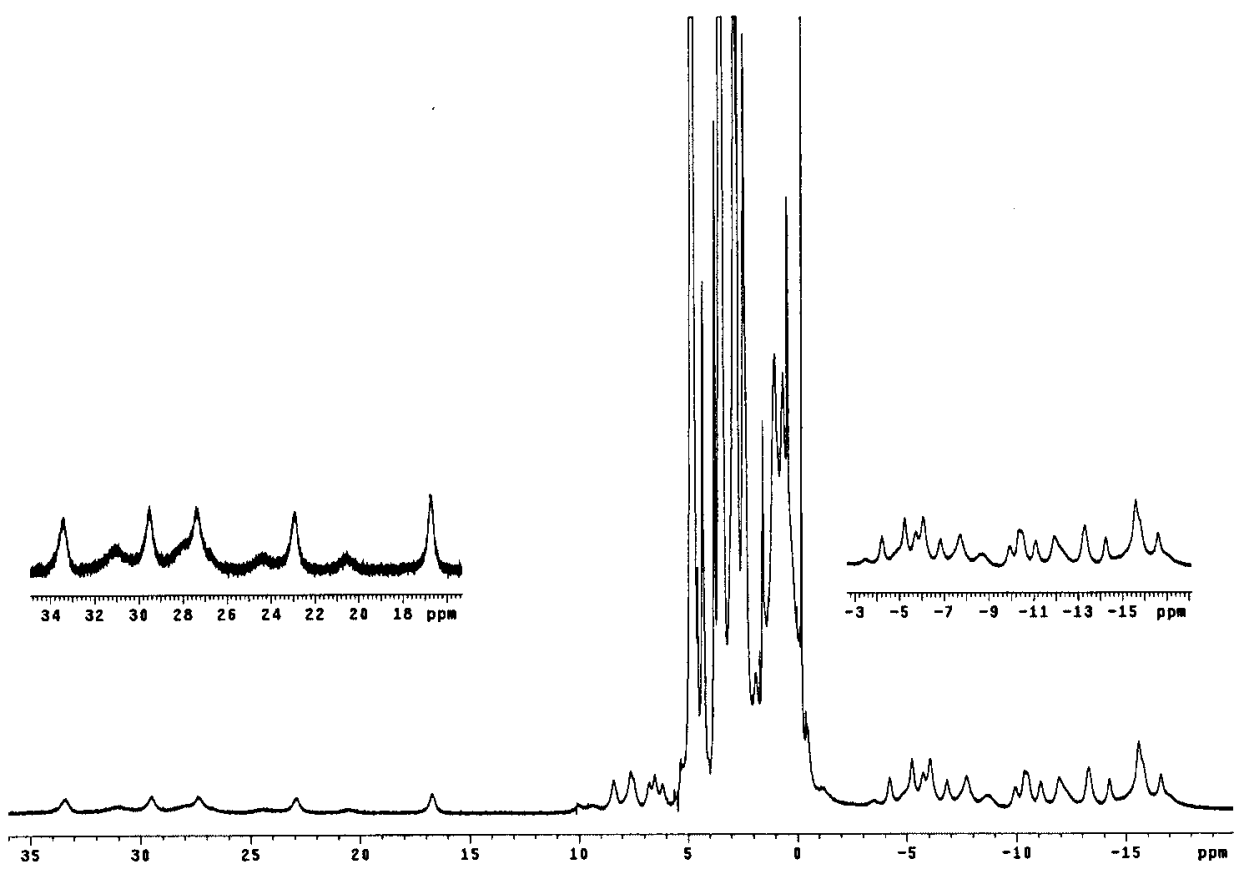

Figure 4. ${ }^{1} \mathrm{H}$ NMR spectrum of Eu ${ }^{\mathrm{III}}-\mathrm{DTPAGal}$ glycoconjugate in $\mathrm{D}_{2} \mathrm{O}, \mathrm{pH}=7.0, T=7{ }^{\circ} \mathrm{C}$.

the strongly shifted resonances at low frequencies for the $\mathrm{Sm}^{\mathrm{III}}$ complex and at high frequencies for the $\mathrm{Eu}^{\mathrm{III}}$ complex correspond to two $\mathrm{CH}_{2}$ protons of the DTPA ethylenediamine backbone, which, in the DTPA complexes, have the largest induced dipolar shifts. ${ }^{[36,39]}$ With this assumption, the minimum of seven low-frequency-shifted resonances observed for the $\mathrm{Sm}^{\mathrm{III}}$ complex at high temperature (Figure 3), resulting from two ethylenic protons, confirms that several of the four possible isomers are present in solution. This is also in agreement with the observation of a mini- 
mum of ten high-frequency-shifted resonances in the $\mathrm{Eu}^{\mathrm{III}}$ complex at high temperature (out of a maximum of sixteen) for these two ethylenic protons (Figure 4). The $\mathrm{Ln}^{\mathrm{III}}$ complexes of other DTPA bis(amides), such as DTPA-BPA $[\mathrm{BPA}=$ bis(propylamide) $]$ and DTPA-BENGALAA $\left\{\right.$ BENGALAA $=N, N^{\prime \prime}$-bis $[N$-(aza-D-galacto-5,6,7,8,9pentahydroxynonyl)carbamoylmethyl]amide $\},{ }^{[35,41]}$ show the presence of four diastereoisomeric pairs, while for bis(amides) containing long $\left(\mathrm{C}_{14}\right.$ to $\left.\mathrm{C}_{18}\right)$ aliphatic chains only two pairs have been detected in solution. ${ }^{[42]}$

\section{Water Proton Relaxation (NMRD) Studies of Gd ${ }^{\text {III }}$ DTPALac $_{2}$}

The efficiency of a contrast agent is given by its proton relaxivity, defined as the paramagnetic enhancement of the longitudinal water proton relaxation rate at a concentration of $1 \mathrm{~mm}\left(r_{1}\right.$, in $\left.\mathrm{s}^{-1} \mathrm{mM}^{-1}\right)$. Proton relaxivity has contributions from interactions of the $\mathrm{Gd}^{\mathrm{III}}$ ion with the innersphere water protons (inner-sphere relaxivity) as well as with the bulk water protons (outer-sphere relaxivity). The inner-sphere term is determined by the exchange rate of the inner-sphere water protons (usually equal to the water exchange rate, $k_{\mathrm{ex}}$ ), the rotational correlation time of the complex $\left(\tau_{\mathrm{R}}\right)$ and the longitudinal and transverse electronic relaxation rates of the $\mathrm{Gd}^{\mathrm{III}}\left(1 / T_{1 \mathrm{e}}\right.$ and $\left.1 / T_{2 \mathrm{e}}\right)$. The outersphere contribution to the overall proton relaxivity depends on the electron spin relaxation rates and the diffusion coefficient for the diffusion of a water proton away from a $\mathrm{Gd}^{\mathrm{III}}$ chelate (see Supporting Information). ${ }^{[43]}$

The water proton longitudinal relaxivity of the $\mathrm{Gd}^{\mathrm{II}}$ DTPALac ${ }_{2}$ chelate was measured in aqueous solution at 25 and $60^{\circ} \mathrm{C}$ at proton Larmor frequencies between 0.2 and $20 \mathrm{MHz}$. The NMRD profiles obtained (Figure 5) are typical of low molecular weight $\mathrm{Gd}^{\mathrm{III}}$ chelates. They were fitted to the usual Solomon-Bloembergen-Morgan relationship that relates the paramagnetic relaxation rates to the microscopic parameters of the $\mathrm{Gd}^{\mathrm{III}}$ chelates (see equations in Supporting Information). In the analysis of the NMRD profiles we fixed the number of inner-sphere water molecules to one, and the water exchange rate and its activation enthalpy to values that were previously determined for similar DTPA bis(amide) complexes $\left(k_{\mathrm{ex}}{ }^{298}=0.40 \times 10^{6} \mathrm{~s}^{-1}\right.$ and $\left.\Delta H^{*}=40.0 \mathrm{~kJ} \mathrm{~mol}^{-1}\right) .{ }^{[43]}$ The diffusion coefficient and its activation energy were also fixed to common values $\left(D_{\mathrm{GdH}}{ }^{298}=24 \times 10^{-10} \mathrm{~m}^{2} \mathrm{~s}^{-1} ; E_{\mathrm{DGdH}}=20 \mathrm{~kJ} \mathrm{~mol}^{-1}\right)$, as these two parameters are not particularly dependent on the nature of low molecular weight complexes. ${ }^{[43,44]}$ Thus, in the analysis of the proton relaxivities we fitted the rotational correlation time, $\tau_{\mathrm{R}}$, its activation energy, $E_{\mathrm{R}}$, and the parameters describing the electron spin relaxation, i.e. the trace of the square of the transient zero-field-splitting (ZFS) tensor, $\Delta^{2}$, and the correlation time for the modulation of the ZFS, $\tau_{\mathrm{v}^{*}}{ }^{[45]}$ The parameters obtained for the Gd $^{\text {III-DTPALac }}{ }_{2}$ conjugate are presented in Table 1 and compared with those available for other relevant small $\mathrm{Gd}^{\mathrm{III}}$ complexes. The fits of the NMRD profiles obtained are shown in Figure 5.

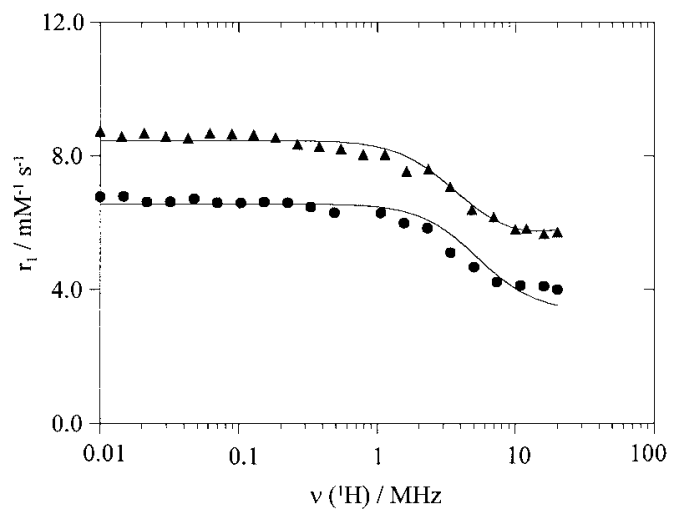

Figure 5. Variable-temperature NMRD profiles for $\mathrm{Gd}^{\mathrm{III}}$-DTPA$\mathrm{Lac}_{2} ; T=25^{\circ} \mathrm{C}$ (triangles); and $60{ }^{\circ} \mathrm{C}$ (circles). The lines represent the least-squares fit to the experimental data points as described in the text.

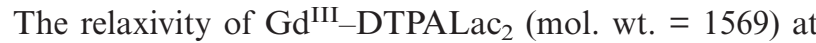
$25^{\circ} \mathrm{C}$ and $20 \mathrm{MHz}$ is $5.72 \mathrm{~mm}^{-1} \mathrm{~s}^{-1}$, which corresponds to an increase of $13 \%$ compared to that for the commercial contrast agent $\mathrm{Gd}^{\mathrm{III}}$-DTPA-BMA, which is a lower molecular weight DTPA bis(amide) complex (mol. wt. = 574). ${ }^{[4]}$ This relaxivity difference is consistent with the fivefold increase in the rotational correlation time, as it is $\tau_{R}$ that dominates the high-field NMRD values. Another

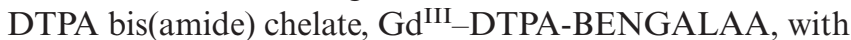
an intermediate molecular weight (963), also has an intermediate $\tau_{\mathrm{R}}$ value. ${ }^{[41]}$ The temperature dependence of the NMRD profiles clearly shows that the proton relaxivity of these small molecular weight chelates is limited by fast rotation: proton relaxivities increase when the temperature decreases; thus, the rotation slows down. The parameters obtained for the electron spin relaxation of the $\mathrm{Gd}^{\mathrm{III}}$ complex

Table 1. Parameters obtained from the analysis of the NMRD profiles for Gd ${ }^{\mathrm{III}}-\mathrm{DTPALac}{ }_{2}$ in comparison with other Gd ${ }^{\mathrm{III}}$ complexes.

\begin{tabular}{|c|c|c|c|c|c|}
\hline & $\mathrm{DTPA}^{[44]}$ & $\begin{array}{l}\text { DTPA-BMA }{ }^{[44]} \\
\text { [bis(amide)] }\end{array}$ & $\begin{array}{l}\text { DTPA-BENGALAA }{ }^{[41]} \\
\text { [bis(amide)] }\end{array}$ & $\begin{array}{l}\text { DTPALac }_{2} \\
\text { [bis(amide)] }\end{array}$ & $\begin{array}{l}\text { DOTALac }_{2}{ }^{[26]} \\
{[\text { mono(amide)] }}\end{array}$ \\
\hline$k_{\mathrm{ex}}^{298}\left[10^{6} \mathrm{~s}^{-1}\right]$ & 3.3 & 0.45 & 0.22 & $0.40^{[\mathrm{a}]}$ & $1.2^{[\mathrm{a}]}$ \\
\hline$\Delta H^{*}\left[\mathrm{~kJ} \mathrm{~mol}^{-1}\right]$ & 51.6 & 47.6 & 42.5 & $40.0^{[\mathrm{a}]}$ & $30.0^{[\mathrm{a}]}$ \\
\hline$\tau_{\mathrm{rH}}{ }^{298}[\mathrm{ps}]$ & 58 & 66 & 265 & $332 \pm 10$ & 306 \\
\hline$E_{\mathrm{RH}}\left[\mathrm{kJ} \mathrm{mol}^{-1}\right]$ & 17.3 & 21.9 & 19.7 & $36.3 \pm 0.2$ & 29.9 \\
\hline$\tau_{\mathrm{v}}^{298}[\mathrm{ps}]$ & 25 & 25 & 16 & $10 \pm 2$ & 33 \\
\hline$E_{\mathrm{v}}\left[\mathrm{kJ} \mathrm{mol}^{-1}\right]$ & 1.6 & 3.9 & 5.5 & $l^{[\mathrm{a}]}$ & $1^{[\mathrm{a}]}$ \\
\hline$\Delta^{2}\left[10^{20} \mathrm{~s}^{-2}\right]$ & 0.46 & 0.41 & 0.53 & $0.63 \pm 0.02$ & 0.12 \\
\hline
\end{tabular}

[a] Parameters in italics have been fixed in the fit. 
are also within the usual range for similar Gd ${ }^{\mathrm{III}}$-DTPA bis(amide) chelates. Although the simplified model of electron spin relaxation used here is not fully adequate to describe $\mathrm{Gd}^{\mathrm{III}}$ chelates, ${ }^{[46]}$ the application of the novel theories requires EPR data in a large field range, which is beyond the scope of the present study.

\section{Conclusions}

We have devised the synthesis of a new class of hydrophilic glycoconjugate DTPA bisamides. Their dendrimeric architecture is especially suited for the variation of the valence of the glycoconjugates from a reduced number of building blocks in an interactive fashion. The ${ }^{1} \mathrm{H}$ NMR studies of the $\mathrm{Sm}^{\mathrm{III}}$ and $\mathrm{Eu}^{\mathrm{III}}$ chelates of these glycoconjugates in aqueous solution, despite being too complex to be fully assigned, unambiguously show that these complexes occur as more than one of the isomers that result from the chirality of the three bound ligand nitrogen atoms. This is to be compared with the presence of the four possible diastereoisomeric pairs of enantiomers for the $\mathrm{Ln}^{\mathrm{III}}$ complexes of other DTPA bis(amides) with smaller substituents, such as DTPA-BMA and DTPA-BENGALAA, ${ }^{[35,41]}$ while for bis(amides) containing long, micelle-forming, aliphatic chains, only two pairs have been detected in solution, ${ }^{[42]}$ possibly stabilized by intermolecular interactions.

The NMRD studies of the Gd ${ }^{\mathrm{III}}-\mathrm{DTPALac}{ }_{2}$ glycoconjugate chelate are compatible with the presence of one inner-sphere water molecule. The value found for its $r_{1}$ relaxivity at $25^{\circ} \mathrm{C}$ and $20 \mathrm{MHz}$ is $13 \%$ higher than that reported for $\mathrm{Gd}^{\mathrm{III}}$ chelates of lower molecular weight DTPA bis(amides), such as DTPA-BMA, consistent with a larger $\tau_{\mathrm{R}}$ value. The $\tau_{\mathrm{R}}$ value of these $\mathrm{Gd}^{\mathrm{III}}$ chelates is expected to increase linearly with molecular weight, as long as the internal mobility of the side chains does not change significantly, thereby leading to a proportional increase of the $20 \mathrm{MHz}$ relaxivity. This result suggests that the relaxivity of the tetravalent $\mathrm{Gd}^{\mathrm{III}}$-DTPAGal 4 glycoconjugate (mol. wt. $=2088$ ) would be substantially higher. Their potential to target the ASGPR (studies under way), makes these compounds potentially useful for medical imaging agents using gamma scintigraphy, while they also constitute a promising first step towards the design of ASGPR-targeted MRI contrast agents, which will depend on the optimisation of their relaxivity.

\section{Experimental Section}

Materials and Equipment: Chemicals were purchased from SigmaAldrich and used without further purification. Solvents used were of reagent grade and were purified by usual methods. Reactions were monitored by TLC on Kieselgel $60 \mathrm{~F}_{254}$ (Merck) on aluminium support. Detection was by examination under UV light $(254 \mathrm{~nm})$, by adsorption of iodine vapour or by charring with $10 \%$ sulfuric acid in ethanol. Flash chromatography was performed on Kieselgel 60 (Merck, mesh 230-400). The relevant fractions from flash chromatography were pooled and concentrated under reduced pressure, at a temperature below $40^{\circ} \mathrm{C}$. FAB mass spectra (positive mode) were recorded with a VG Autospec mass spectrometer with 3-nitrobenzyl alcohol (NBA) as matrix. Electrospray ionisation (ESI) mass spectra were obtained for compounds with molecular weights above 2000. ${ }^{1} \mathrm{H}$ (1D and 2D) and ${ }^{13} \mathrm{C}$ NMR spectra were recorded with a Varian Unity Plus 300 NMR spectrometer operating at $299.938 \mathrm{MHz}$ and $75.428 \mathrm{MHz}$, for ${ }^{1} \mathrm{H}$ and ${ }^{13} \mathrm{C}$, respectively. Chemical shifts $(\delta)$ are given in ppm relative to the $\mathrm{CDCl}_{3}$ solvent ( $\left.{ }^{1} \mathrm{H}: \delta=7.27 \mathrm{ppm} ;{ }^{13} \mathrm{C}: \delta=77.36 \mathrm{ppm}\right)$ as internal standard. For ${ }^{1} \mathrm{H}$ and ${ }^{13} \mathrm{C}$ NMR spectra recorded in $\mathrm{D}_{2} \mathrm{O}$, chemical shifts $(\delta)$ are given in ppm relative to TSP as internal reference $\left({ }^{1} \mathrm{H}\right.$ : $\delta=0.0 \mathrm{ppm})$ and tert-butyl alcohol as external reference $\left({ }^{13} \mathrm{C}: \mathrm{CH}_{3}\right.$ $\delta=30.29 \mathrm{ppm}) .{ }^{13} \mathrm{C}$ NMR spectra were proton broad-band decoupled using a GARP-1 modulated decoupling scheme. Assignments of the ${ }^{1} \mathrm{H}$ and ${ }^{13} \mathrm{C}$ NMR spectra were aided by recording twodimensional DQF-COSY and HMQC spectra. The $\mathrm{pD}$ of the $\mathrm{D}_{2} \mathrm{O}$ solutions was adjusted with $\mathrm{DCl}$ or $\mathrm{CO}_{2}$-free $\mathrm{NaOD}$ and converted to $\mathrm{pH}$ values using the isotopic correction $\mathrm{pH}=\mathrm{pD}-0.4$. The $\mathrm{pD}$ values were measured with a HANNA pH-meter with a HI1310 combined electrode (HANNA instruments, Italy). The $1 / T_{1}$ nuclear magnetic relaxation dispersion (NMRD) profiles of the water protons at 25 and $60{ }^{\circ} \mathrm{C}$ were obtained with a Spinmaster FFC fast cycling NMR relaxometer (Stelar), covering a continuum of magnetic fields from $5 \times 10^{-4}$ to $0.47 \mathrm{~T}$ (corresponding to a proton Larmor frequency range of $0.022-20 \mathrm{MHz}$ ). The $\mathrm{Gd}^{\mathrm{III}}$ concentration was verified by ICP measurement (Perkin-Elmer Instruments, Optim 2000 DV).

Synthesis of Fully Protected Hexanediamine-Functionalised Monovalent Thioglycosides 5a and 5b. Typical Procedure for 5a: A solution of peracetylated (galactosylthio)propionic acid (3a; ; ${ }^{[29 a]}$ $0.375 \mathrm{~g}, 0.859 \mathrm{mmol}), 1,6$-hexanediamine monoBoc $(4 ; 0.169 \mathrm{~g}$, $0.781 \mathrm{mmol}$ ) and HBT (1-hydroxybenzotriazol; $0.140 \mathrm{~g}$, $0.940 \mathrm{mmol})$ in dichloromethane $(10 \mathrm{~mL})$ was ice-cooled. A solution of DCC (dicyclohexylcarbodiimide; $0.194 \mathrm{~g}, 9.40 \mathrm{mmol}$ ) in dichloromethane $(5 \mathrm{~mL})$ was added dropwise to this solution. After $15 \mathrm{~min}$, the reaction mixture was removed from the ice bath and allowed to reach room temperature. The reaction mixture was further stirred at room temperature overnight. The DCU (dicyclohexylurea) precipitate was removed by filtration and washed with dichloromethane. The filtrate was concentrated under reduced pressure to give a viscous syrup. This material was taken up in ethyl acetate $\left(100 \mathrm{~mL}\right.$ ) and sequentially washed with $\mathrm{KHSO}_{4}$ (aq. $1 \mathrm{M}$; $3 \times 50 \mathrm{~mL}$ ), $\mathrm{NaHCO}_{3}$ (satd. sol.; $3 \times 50 \mathrm{~mL}$ ) and brine $(50 \mathrm{~mL})$. The organic phase was concentrated under reduced pressure to give a white foam. Purification by flash chromatography $\left(\mathrm{CH}_{2} \mathrm{Cl}_{2} / \mathrm{MeOH}\right.$; $\left.100 \% \mathrm{CH}_{2} \mathrm{Cl}_{2} \rightarrow 50 \% \mathrm{MeOH}\right)$ afforded the title compound as a white foam $\left(0.480 \mathrm{~g}, 97 \%\right.$ yield). ${ }^{1} \mathrm{H}$ NMR $\left(300 \mathrm{MHz}, \mathrm{CDCl}_{3}\right): \delta$ $=1.34\left(\mathrm{~m}, 4 \mathrm{H}, \mathrm{NHCH}_{2} \mathrm{CH}_{2} \mathrm{CH}_{2}\right), 1.43(\mathrm{~s}, 9 \mathrm{H}, t \mathrm{Bu}), 1.50(\mathrm{~m}, 4$ $\mathrm{H}, \mathrm{NHCH}_{2} \mathrm{CH}_{2}$ ), 1.99, 2.05, 2.06 and 2.16 (s, $\left.12 \mathrm{H}, 4 \times \mathrm{OAc}\right), 2.50$ $\left(\mathrm{m}, 2 \mathrm{H}, \mathrm{SCH}_{2} \mathrm{CH}_{2}\right), 2.88-3.06(\mathrm{~m}, 2 \mathrm{H}, \mathrm{SCH}), 3.09[\mathrm{~m}, 2 \mathrm{H}$, $\left.\mathrm{CH}_{2} \mathrm{NHC}(\mathrm{O}) \mathrm{O} t \mathrm{Bu}\right], 3.24$ [m, $2 \mathrm{H}, \mathrm{C}(\mathrm{O}) \mathrm{NHCH}_{2}$ ], 3.48 (br. m, $\left.1 \mathrm{H}\right)$, 3.95 (ddd, $J=7.2,5.7$ and $0.9 \mathrm{~Hz}, 1 \mathrm{H}, \mathrm{H}-5), 4.11$ (dd, $J=11.2$ and $5.7 \mathrm{~Hz}, 1 \mathrm{H}, \mathrm{H}-6 \mathrm{a}), 4.19$ (dd, $J=11.2$ and $7.2 \mathrm{~Hz}, 1 \mathrm{H}, \mathrm{H}-6 \mathrm{~b}$ ), $4.54(\mathrm{~d}, J=9.9 \mathrm{~Hz}, 1 \mathrm{H}, \mathrm{H}-1), 5.04(\mathrm{dd}, J=10.2$ and $3.3 \mathrm{~Hz}, 1 \mathrm{H}$, $\mathrm{H}-3$ ), 5.23 (app t, $J=9.9 \mathrm{~Hz}, 1 \mathrm{H}, \mathrm{H}-2), 5.43$ (dd, $J=3.3$ and $0.9 \mathrm{~Hz}, 1 \mathrm{H}, \mathrm{H}-4), 5.98$ (br. t, $1 \mathrm{H}, \mathrm{NH})$ ppm. HRMS $\left(\mathrm{FAB}^{+}\right.$, NBA): calcd. for $\mathrm{C}_{28} \mathrm{H}_{47} \mathrm{~N}_{2} \mathrm{O}_{12} \mathrm{~S}[\mathrm{M}+\mathrm{H}]^{+}$635.2844; found 635.2856. 5b: Starting from peracetylated (lactosylthio)propionic acid (3b; $\left.{ }^{[29 a]} 1.70 \mathrm{~g}, 2.35 \mathrm{mmol}\right)$ and 1,6-hexanediamine monoBoc (4; $0.507 \mathrm{~g}, 2.35 \mathrm{mmol})$, the title compound $\mathbf{5 b}$ was obtained as a white foam $(2.01 \mathrm{~g}, 93 \%) .{ }^{1} \mathrm{H}$ NMR $\left(300 \mathrm{MHz}, \mathrm{CDCl}_{3}\right): \delta=1.33$ $\left(\mathrm{m}, 4 \mathrm{H}, \mathrm{NHCH}_{2} \mathrm{CH}_{2} \mathrm{CH}_{2}\right), 1.42(\mathrm{~s}, 9 \mathrm{H}, t \mathrm{Bu}), 1.70(\mathrm{~m}, 4 \mathrm{H}$, $\left.\mathrm{NHCH}_{2} \mathrm{CH}_{2}\right), 1.97,2.04,2.05,2.07,2.13$ and $2.16(\mathrm{~s}, 21 \mathrm{H}$, $7 \times \mathrm{OAc}), 2.46\left(\mathrm{t}, J=6.6 \mathrm{~Hz}, 2 \mathrm{H}, \mathrm{SCH}_{2} \mathrm{CH}_{2}\right), 2.81(\mathrm{~m}, 1 \mathrm{H}$, 
$\left.\mathrm{SCH}_{a} \mathrm{H}_{\mathrm{b}}\right), 3.03\left(\mathrm{~m}, 1 \mathrm{H}, \mathrm{SCH}_{\mathrm{a}} H_{b}\right), 3.08\left[\mathrm{~m}, 2 \mathrm{H}, \mathrm{CH}_{2} \mathrm{NHC}(\mathrm{O})-\right.$ $\mathrm{O} t \mathrm{Bu}], 3.21\left(\mathrm{~m}, 2 \mathrm{H}, \mathrm{NHCH} \mathrm{C}_{2}\right), 3.45(\mathrm{~m}, 1 \mathrm{H}) 3.59(\mathrm{~m}, 1 \mathrm{H}, \mathrm{H}-5)$, $3.78(\operatorname{app~t} J=9.6 \mathrm{~Hz}, 1 \mathrm{H}, \mathrm{H}-4), 3.89(\operatorname{app~t}, J=7.0 \mathrm{~Hz}, 1 \mathrm{H}, \mathrm{H}-$ 5'), 4.03-4.16 (m, $3 \mathrm{H}), 4.28(\mathrm{~m}, 1 \mathrm{H}), 4.52(\mathrm{~d}, J=7.8 \mathrm{~Hz}, 1 \mathrm{H}, \mathrm{H}-$ $\left.1^{\prime}\right), 4.65(\mathrm{~d}, J=10.5 \mathrm{~Hz}, 1 \mathrm{H}, \mathrm{H}-1), 4.90(\operatorname{app~t}, J=9.6 \mathrm{~Hz}, 1 \mathrm{H}$, H-2), 4.96 (dd, $J=10.2$ and $\left.3.3 \mathrm{~Hz}, 1 \mathrm{H}, \mathrm{H}-3^{\prime}\right), 5.09$ (dd, $J=10.5$ and $\left.7.8 \mathrm{~Hz}, 1 \mathrm{H}, \mathrm{H}-2^{\prime}\right), 5.19$ (app t, $\left.J=9.3 \mathrm{~Hz}, 1 \mathrm{H}, \mathrm{H}-3\right), 5.34$ (d, $\left.J=2.4 \mathrm{~Hz}, 1 \mathrm{H}, \mathrm{H}-4^{\prime}\right), 6.30$ (br. t, $\left.2 \mathrm{H}, N H \mathrm{CO}\right)$ ppm. MS (FAB ${ }^{+}$, NBA): $m / z(\%)=923(3)[\mathrm{M}+\mathrm{H}]^{+}$. HRMS $\left(\mathrm{FAB}^{+}\right.$, NBA): calcd. for $\mathrm{C}_{40} \mathrm{H}_{63} \mathrm{~N}_{2} \mathrm{O}_{20} \mathrm{~S}[\mathrm{M}+\mathrm{H}]^{+}$923.3695; found 923.3683 .

Synthesis of Fully Protected Amino-Functionalised Divalent 9: A solution of divalent thiogalactoside $7^{[26]}(0.968 \mathrm{~g}, 0.895 \mathrm{mmol})$ was stirred overnight in $\mathrm{CH}_{2} \mathrm{Cl}_{2} / \mathrm{TFA}(3: 1,10 \mathrm{~mL})$. The solvent was removed under reduced pressure to give a light yellow foam, which was redissolved in dichloromethane (DCM; $10 \mathrm{~mL})$. The solvent was then removed under reduced pressure. This procedure was repeated several times and the material was further dried under vacuum to give the carboxylic acid deprotected compound $\mathbf{8}$ as a viscous, light-yellow foam. ${ }^{1} \mathrm{H}$ NMR analysis revealed the disappearance of the signal at $\delta=1.4 \mathrm{ppm}$ assigned to the tert-butyl group. No further purification or characterisation was carried on this material. All the material obtained (we assumed a $100 \%$ yield for the deprotection reaction) was dissolved in ice-cooled DCM $(10 \mathrm{~mL})$ and titrated ( $\mathrm{pH}$ paper) to $\mathrm{pH}=9-10$ with DIPEA (diisopropylethylamine). To this solution was added a solution of 1,6-hexanediamine monoBoc $(4 ; 0.230 \mathrm{~g}, 1.07 \mathrm{mmol})$ in dichloromethane $(5 \mathrm{~mL})$ and HBT $(0.140 \mathrm{~g}, 0.940 \mathrm{mmol})$. A solution of DCC $(0.230 \mathrm{~g}$, $1.10 \mathrm{mmol})$ in dichloromethane $(5 \mathrm{~mL})$ was then added dropwise. After $15 \mathrm{~min}$, the reaction mixture was removed from the ice bath and allowed to reach room temperature. The reaction mixture was further stirred at room temperature overnight. The DCU precipitate was removed by filtration and washed with dichloromethane. The filtrate was concentrated under reduced pressure to give a viscous syrup. This material was taken up in ethyl acetate $(150 \mathrm{~mL})$ and sequentially washed with $\mathrm{NaHCO}_{3}$ (satd. sol.; $3 \times 100 \mathrm{~mL}$ ) and brine $(100 \mathrm{~mL})$. The organic phase was concentrated under reduced pressure to give a light-yellow foam. Purification by flash chromatography $\left(\mathrm{CH}_{2} \mathrm{Cl}_{2} / \mathrm{MeOH} ; 100 \% \mathrm{CH}_{2} \mathrm{Cl}_{2} \rightarrow 50 \% \mathrm{MeOH}\right)$ afforded the title compound as a white foam $(1.01 \mathrm{~g}, 92 \%$ yield). ${ }^{1} \mathrm{H}$ NMR $\left(300 \mathrm{MHz}, \mathrm{CDCl}_{3}\right): \delta=1.32[\mathrm{~m}, 4 \mathrm{H}, \mathrm{C}(\mathrm{O})$ $\left.\mathrm{NHCH}_{2} \mathrm{CH}_{2} \mathrm{CH}_{2}\right], 1.43(\mathrm{~s}, 9 \mathrm{H}, t \mathrm{Bu}), 1.51[\mathrm{~m}, 4 \mathrm{H}, \mathrm{C}(\mathrm{O})$ $\mathrm{NHCH}_{2} \mathrm{CH}_{2}$ ], $1.72\left(\mathrm{~m}, 4 \mathrm{H}, \mathrm{NCH}_{2} \mathrm{CH}_{2}\right), 1.99,2.05,2.06$ and 2.16 $(\mathrm{s}, 24 \mathrm{H}, 8 \times \mathrm{OAc}), 2.52(\mathrm{~m}, 8 \mathrm{H}$, overlapping signals from $\mathrm{SCH}_{2} \mathrm{CH}_{2}$ and $\mathrm{NCH}_{2}$ ), 2.88-3.14 [m, $8 \mathrm{H}$, overlapping signals from $\mathrm{SCH}_{2}, \mathrm{NCH}_{2} \mathrm{C}(\mathrm{O})$ (singlet at 3.02) and $\mathrm{CH}_{2} \mathrm{NHC}(\mathrm{O}) \mathrm{O} t \mathrm{Bu}$ ], 3.29 [m, $6 \mathrm{H}, \mathrm{NCH}_{2} \mathrm{CH}_{2} \mathrm{CH}_{2}$ and $\mathrm{NCH}_{2} \mathrm{C}(\mathrm{O}) \mathrm{NHCH}_{2}$ ], 3.40-3.56 (m, 1 $\mathrm{H}), 3.96(\mathrm{td}, J=6.4$ and $0.9 \mathrm{~Hz}, 2 \mathrm{H}, \mathrm{H}-5), 4.09(\mathrm{dd}, J=11.4$ and $6.3 \mathrm{~Hz}, 2 \mathrm{H}, \mathrm{H}-6 \mathrm{a}$ ), 4.20 (dd, $J=11.2$ and $6.4 \mathrm{~Hz}, 2 \mathrm{H}, \mathrm{H}-6 \mathrm{~b}$ ), 4.56 (d, $J=10.2 \mathrm{~Hz}, 2 \mathrm{H}, \mathrm{H}-1$ ), 4.74 (br. t, $1 \mathrm{H}, \mathrm{NH}$ ), 5.05 (dd, $J=$ 10.0 and $3.3 \mathrm{~Hz}, 2 \mathrm{H}, \mathrm{H}-3$ ), 5.25 (app t, $J=9.9 \mathrm{~Hz}, 2 \mathrm{H}, \mathrm{H}-2$ ), 5.44 (dd, $J=3.3$ and $0.9 \mathrm{~Hz}, 2 \mathrm{H}, \mathrm{H}-4), 6.74$ (br. t, $2 \mathrm{H}, \mathrm{NH}$ ), 7.10 (br. t, $2 \mathrm{H})$ ppm. MS (FAB $\left.{ }^{+}, \mathrm{NBA}\right): m / z(\%)=1223(100)[\mathrm{M}-\mathrm{H}]^{+}$. HRMS (FAB ${ }^{+}$, NBA): calcd. for $\mathrm{C}_{53} \mathrm{H}_{86} \mathrm{~N}_{5} \mathrm{O}_{23} \mathrm{~S}_{2}[\mathrm{M}+\mathrm{H}]^{+}$ 1224.5155; found 1224.5119 .

Synthesis of DTPA Glycoconjugate Bis(amides9 1 and 2. Typical Procedure Illustrated for DTPAGal 2 (1a): A solution of fully protected amino-functionalised monovalent thiogalactoside 5a (0.618 g, $0.973 \mathrm{mmol})$ was stirred overnight in $\mathrm{CH}_{2} \mathrm{Cl}_{2} / \mathrm{TFA}$ (3:1, $10 \mathrm{~mL}$ ). The solvent was removed under reduced pressure to give a light-yellow foam, which was redissolved in DCM $(10 \mathrm{~mL})$; the solvent was then removed under reduced pressure. This procedure was repeated several times and the material was further dried under vacuum to give a viscous, light-yellow foam of $6 \mathbf{6}$. ${ }^{1} \mathrm{H}$ NMR analy- sis revealed the disappearance of the signal at $\delta=1.47 \mathrm{ppm}$ assigned to the tert-butyl group. No further purification or characterisation was carried out on this material. All the material obtained (we assumed a $100 \%$ yield for the deprotection reaction) was dissolved in ice-cooled DCM $(5 \mathrm{~mL})$ and titrated ( $\mathrm{pH}$ paper) to $\mathrm{pH}$ $=9-10$ with DIPEA. This solution was added to a solution of DTPA bis(anhydride) $(0.158 \mathrm{~g}, 0.442 \mathrm{mmol})$ in DMF $(40 \mathrm{~mL})$ and pyridine $(1 \mathrm{~mL})$. The reaction mixture was stirred at room temperature overnight and concentrated under reduced pressure to give a colourless oil. This material was carried through without further purification or characterisation. The residue was redissolved in a mixture of ethanol $(10 \mathrm{~mL})$ and $\mathrm{KOH}$ (aq. sol. $1 \mathrm{M}, 10 \mathrm{~mL}$ ) and stirred at room temperature overnight. The reaction mixture was adjusted to $\mathrm{pH} \approx 1$ with Amberlyst 15 . The resin was transferred into a column, thoroughly washed with water and eluted with aq. $0.5 \mathrm{M} \mathrm{NH}_{3}$. The relevant fractions were pooled and concentrated under reduced pressure (temperature $<40^{\circ} \mathrm{C}$ ) to give the fully deprotected glycoconjugate as an off-white solid $(0.342 \mathrm{~g}, 71 \%$ yield over two steps). ${ }^{1} \mathrm{H}$ NMR (300 MHz, $\left.\mathrm{D}_{2} \mathrm{O}, \mathrm{pH}=7.0\right): \delta=4.48(\mathrm{~d}$, $J=9.0 \mathrm{~Hz}, 2 \mathrm{H}, \mathrm{H}-1$ ), 3.54 (app t, $J=9.0 \mathrm{~Hz}, 2 \mathrm{H}, \mathrm{H}-2$ ), 3.64 (dd, $J=9.0$ and $3.3 \mathrm{~Hz}, 2 \mathrm{H}, \mathrm{H}-3), 3.70(\mathrm{~m}, 2 \mathrm{H}, \mathrm{H}-4), 3.96$ (app d, $J$ $=3.3 \mathrm{~Hz}, 2 \mathrm{H}, \mathrm{H}-5), 3.73(\mathrm{~m}, 4 \mathrm{H}, \mathrm{H}-6 \mathrm{a}+\mathrm{H}-6 \mathrm{~b}), 1.32[\mathrm{~m}, 8 \mathrm{H}$, $\mathrm{C}(\mathrm{O}) \mathrm{NHCH}_{2} \mathrm{CH}_{2} \mathrm{CH}_{2}$ ] $, 1.51\left[\mathrm{~m}, 8 \mathrm{H}, \mathrm{C}(\mathrm{O}) \mathrm{NHCH}_{2} \mathrm{CH}_{2}\right], 3.20$ [m, $\left.8 \mathrm{H}, \mathrm{C}(\mathrm{O}) \mathrm{NHCH}_{2}\right], 2.60\left(\mathrm{~m}, 4 \mathrm{H}, \mathrm{SCH}_{2} \mathrm{CH}_{2}\right), 2.95-3.01(\mathrm{~m}, 4 \mathrm{H}$, $\mathrm{SCH}_{2}$ ), 3.24 [s, $4 \mathrm{H}$, DTPA amide $\mathrm{NCH}_{2} \mathrm{C}(\mathrm{O})$ ], 3.76 (s, $2 \mathrm{H}$, DTPA central acetate $\left.\mathrm{NCH}_{2} \mathrm{CO}_{2}^{-}\right), 3.40(\mathrm{~s}, 4 \mathrm{H}$, DTPA terminal acetate $\mathrm{NCH}_{2} \mathrm{CO}_{2}^{-}$), 3.34, 3.08 (two m, $8 \mathrm{H}$, DTPA skeleton $\mathrm{NCH}_{2}$ ) ppm. ${ }^{13} \mathrm{C}$ NMR (75.6 MHz, $\left.\mathrm{D}_{2} \mathrm{O}\right): \delta=86.18(\mathrm{C}-1), 69.67(\mathrm{C}-2), 74.05$ (C-3), 79.07 (C-4), 68.94 (C-5), 61.30 (C-6), 25.90, 25.83 [C(O) $\left.\mathrm{NHCH}_{2} \mathrm{CH}_{2} \mathrm{CH}_{2}\right], 28.29,28.42\left[\mathrm{C}(\mathrm{O}) \mathrm{NHCH}_{2} \mathrm{CH}_{2}\right], 39.23,39.54$ $\left[\mathrm{C}(\mathrm{O}) \mathrm{NHCH}_{2}\right], 26.49\left(\mathrm{SCH}_{2}\right), 36.57\left(\mathrm{SCH}_{2} \mathrm{CH}_{2}\right), 58.86$ [DTPA amide $\mathrm{NCH}_{2} \mathrm{C}(\mathrm{O})$ ], 54.58 (DTPA central acetate $\mathrm{NCH}_{2} \mathrm{CO}_{2}^{-}$), 58.95 (DTPA terminal acetate $\mathrm{NCH}_{2} \mathrm{CO}_{2}^{-}$), 50.59, 52.79 (DTPA skeleton $\mathrm{NCH}_{2}$ ), 170.77, 173.02, 174.28, 178.40 [DTPA acetate $\mathrm{NCH}_{2} \mathrm{CO}_{2}^{-}$and amide $\mathrm{NCH}_{2} \mathrm{C}(\mathrm{O})$, other $\left.\mathrm{CH}_{2} \mathrm{C}(\mathrm{O}) \mathrm{NH}\right]$ ppm. MS $\left(\mathrm{FAB}^{+}, \mathrm{NBA}\right): m / z(\%)=1091(23)\left[\mathrm{M}+\mathrm{H}^{+}\right]$. HRMS $\left(\mathrm{FAB}^{+}\right.$, NBA) calcd. for $\mathrm{C}_{44} \mathrm{H}_{80} \mathrm{~N}_{7} \mathrm{O}_{20} \mathrm{~S}_{2}[\mathrm{M}+\mathrm{H}]^{+}$: 1090.4899; found 1090.4859 .

DTPALac $_{2}$ (1b): Fully protected monovalent thiolactoside 5b $(0.997 \mathrm{~g}, 1.08 \mathrm{mmol})$ was deprotected as described for compound 1a. Reaction with DTPA bis(anhydride) ( $0.183 \mathrm{~g}, 0.512 \mathrm{mmol})$, followed by deprotection and purification afforded glycoconjugate $\mathbf{1 b}$ as an off-white solid ( $0.345 \mathrm{~g}, 48 \%$ yield over two steps). ${ }^{1} \mathrm{H}$ NMR (300 MHz, $\left.\mathrm{D}_{2} \mathrm{O}, \mathrm{pH}=7.0\right): \delta=4.46(\mathrm{~d}, J=7.8 \mathrm{~Hz}, 2 \mathrm{H}, \mathrm{H}-1)$, 3.54 (dd, $J=10.2$ and $7.8 \mathrm{~Hz}, 2 \mathrm{H}, \mathrm{H}-2), 3.63$ (dd, $J=10.2$ and $3.3 \mathrm{~Hz}, 2 \mathrm{H}, \mathrm{H}-3), 3.66$ (m, $2 \mathrm{H}, \mathrm{H}-4), 3.94$ (app d, $J=3.3 \mathrm{~Hz}, 2$ H, H-5), 3.70 (m, 4 H, H-6a + H-6b), 4.58 (d, $J=10.2 \mathrm{~Hz}, 2 \mathrm{H}$, H-1'), 3.36 (app t, 2 H, H-2'), 3.64 (app t, 2 H, H-3'), 3.68 (dd, 2 $\left.\mathrm{H}, \mathrm{H}-4^{\prime}\right), 3.99$ (m, $\left.2 \mathrm{H}, \mathrm{H}-5^{\prime}\right), 3.72$ (m, 4 H, H-6a' + H-6b'; Gal unit: H-1-H-6b; Gluc unit: $\left.\mathrm{H}-1^{\prime}-\mathrm{H}-6 \mathrm{~b}^{\prime}\right), 1.32$ [m, $8 \mathrm{H}, \mathrm{C}(\mathrm{O})-$ $\left.\mathrm{NHCH}_{2} \mathrm{CH}_{2} \mathrm{CH}_{2}\right], 1.52\left[\mathrm{~m}, 8 \mathrm{H}, \mathrm{C}(\mathrm{O}) \mathrm{NHCH}_{2} \mathrm{CH}_{2}\right], 3.20[\mathrm{~m}, 8 \mathrm{H}$, $\left.\mathrm{C}(\mathrm{O}) \mathrm{NHCH}_{2}\right], 2.61\left(\mathrm{~m}, 4 \mathrm{H}, \mathrm{SCH}_{2} \mathrm{CH}_{2}\right), 2.98-3.01(\mathrm{~m}, 4 \mathrm{H}$, $\left.\mathrm{SCH}_{2}\right), 3.23$ [s, $4 \mathrm{H}$, DTPA amide $\left.\mathrm{NCH}_{2} \mathrm{C}(\mathrm{O})\right], 3.76$ (s, $2 \mathrm{H}$, DTPA central acetate $\left.\mathrm{NCH}_{2} \mathrm{CO}_{2}^{-}\right), 3.38(\mathrm{~s}, 4 \mathrm{H}$, DTPA terminal acetate $\mathrm{NCH}_{2} \mathrm{CO}_{2}^{-}$), 3.37, 3.08 (8 H, two m, DTPA skeleton $\left.\mathrm{NCH}_{2}\right) \mathrm{ppm}$. ${ }^{13} \mathrm{C}$ NMR (75.6 MHz, $\left.\mathrm{D}_{2} \mathrm{O}\right): \delta=103.08(\mathrm{C}-1), 71.15(\mathrm{C}-2), 78.42$ (C-3), 72.71 (C-4), 60.49 (C-5), 75.55 (C-6), 85.59 (C-1'), 72.11 (C2'), 78.82 (C-3'), 75.92 (C-4'), 68.76 (C-5'), 61.22 (C-6') (Gal unit: C-1-C-6; Gluc unit: C-1'-C-6'), 25.86, $25.94 \quad[\mathrm{C}(\mathrm{O})$ $\left.\mathrm{NHCH}_{2} \mathrm{CH}_{2} \mathrm{CH}_{2}\right], 28.33,28.47\left[\mathrm{C}(\mathrm{O}) \mathrm{NHCH}_{2} \mathrm{CH}_{2}\right], 39.26,39.58$ [C(O) $\mathrm{NHCH}_{2}$ ], $26.45\left(\mathrm{SCH}_{2}\right), 36.61\left(\mathrm{SCH}_{2} \mathrm{CH}_{2}\right), 58.86$ [DTPA amide $\mathrm{NCH}_{2} \mathrm{C}(\mathrm{O})$ ], 54.33 (DTPA central acetate $\mathrm{NCH}_{2} \mathrm{CO}_{2}{ }^{-}$), $59.03,59.11$ (DTPA terminal acetate $\mathrm{NCH}_{2} \mathrm{CO}_{2}^{-}$), 50.53, 52.88 
(DTPA skeleton $\mathrm{NCH}_{2}$ ), 170.60, 173.41, 174.24, 178.82 [DTPA acetate $\mathrm{NCH}_{2} \mathrm{CO}_{2}{ }^{-}$and amide $\mathrm{NCH}_{2} \mathrm{C}(\mathrm{O})$, other $\left.\mathrm{CH}_{2} \mathrm{C}(\mathrm{O}) \mathrm{NH}\right]$ ppm. HRMS (ESI): calcd. for $\mathrm{C}_{56} \mathrm{H}_{100} \mathrm{~N}_{7} \mathrm{O}_{30} \mathrm{~S}_{2}[\mathrm{M}+\mathrm{H}]^{+}$1414.5950; found 1414.5971 .

DTPAGal 4 (2): Fully protected amino-functionalised divalent thiogalactoside 9 (0.464 g, $0.379 \mathrm{mmol})$ was deprotected as described for compound 1a. Reaction with DTPA bis(anhydride) $(0.064 \mathrm{~g}$, $0.179 \mathrm{mmol})$, followed by deprotection and purification afforded glycoconjugate 2 as an off-white solid $(0.240 \mathrm{~g}, 69 \%$ yield over two steps). ${ }^{1} \mathrm{H}$ NMR $\left(300 \mathrm{MHz}, \mathrm{D}_{2} \mathrm{O}, \mathrm{pH}=7.0\right): \delta=4.46(\mathrm{~d}, J=$ $9.0 \mathrm{~Hz}, 4 \mathrm{H}, \mathrm{H}-1$ ), 3.52 (app t, $J=9.0 \mathrm{~Hz}, 4 \mathrm{H}, \mathrm{H}-2$ ), 3.64 (dd, $J$ $=9.0$ and $3.3 \mathrm{~Hz}, 4 \mathrm{H}, \mathrm{H}-3), 3.68(\mathrm{~m}, 4 \mathrm{H}, \mathrm{H}-4), 3.95(\operatorname{app} \mathrm{d}, J=$ $3.3 \mathrm{~Hz}, 4 \mathrm{H}, \mathrm{H}-5), 3.71$ (m, $8 \mathrm{H}, \mathrm{H}-6 \mathrm{a}+\mathrm{H}-6 \mathrm{~b}), 1.28$ [m, $8 \mathrm{H}, \mathrm{C}(\mathrm{O})$ $\left.\mathrm{NHCH}_{2} \mathrm{CH}_{2} \mathrm{CH}_{2}\right], 1.49\left[\mathrm{~m}, 8 \mathrm{H}, \mathrm{C}(\mathrm{O}) \mathrm{NHCH}_{2} \mathrm{CH}_{2}\right], 3.18[\mathrm{~m}, 8 \mathrm{H}$, $\mathrm{C}(\mathrm{O}) \mathrm{NHCH}_{2}$ ] $3.48\left[\mathrm{~m}, 4 \mathrm{H}, \mathrm{NCH}_{2} \mathrm{C}(\mathrm{O})\right], 2.75\left(\mathrm{~m}, 8 \mathrm{H}, \mathrm{NCH}_{2}\right)$, $1.83\left(\mathrm{~m}, 8 \mathrm{H}, \mathrm{NCH}_{2} \mathrm{CH}_{2}\right), 3.20\left(\mathrm{~m}, 8 \mathrm{H}, \mathrm{NCH}_{2} \mathrm{CH}_{2} \mathrm{CH}_{2}\right), 2.59$ (m, $\left.8 \mathrm{H}, \mathrm{SCH}_{2} \mathrm{CH}_{2}\right), 2.97$ (m, $\left.8 \mathrm{H}, \mathrm{SCH}_{2}\right), 3.20$ [s, $4 \mathrm{H}$, DTPA amide $\left.\mathrm{NCH}_{2} \mathrm{C}(\mathrm{O})\right], 3.71$ (s, $2 \mathrm{H}$, DTPA central acetate $\mathrm{NCH}_{2} \mathrm{CO}_{2}^{-}$), 3.33 (s, $4 \mathrm{H}$, DTPA terminal acetate $\mathrm{NCH}_{2} \mathrm{CO}_{2}^{-}$), 3.34, 3.18 (two m, 8 $\mathrm{H}$, DTPA skeleton $\left.\mathrm{NCH}_{2}\right)$ ppm. ${ }^{13} \mathrm{C}$ NMR $\left(75.6 \mathrm{MHz}, \mathrm{D}_{2} \mathrm{O}\right): \delta=$ 86.29 (C-1), 69.66 (C-2), 74.09 (C-3), 79.08 (C-4), 68.95 (C-5), 61.41 (C-6), $25.33\left[\mathrm{C}(\mathrm{O}) \mathrm{NHCH}_{2} \mathrm{CH}_{2} \mathrm{CH}_{2}\right], 28.53\left[\mathrm{C}(\mathrm{O}) \mathrm{NHCH}_{2} \mathrm{CH}_{2}\right]$, $39.32,39.18\left[\mathrm{C}(\mathrm{O}) \mathrm{NHCH}_{2}\right], 56.57\left[\mathrm{NCH}_{2} \mathrm{C}(\mathrm{O})\right], 52.51\left(\mathrm{NCH}_{2}\right)$, $25.38\left(\mathrm{NCH}_{2} \mathrm{CH}_{2}\right), 37.11\left(\mathrm{NCH}_{2} \mathrm{CH}_{2} \mathrm{CH}_{2}\right), 26.70\left(\mathrm{SCH}_{2}\right), 36.52$ $\left(\mathrm{SCH}_{2} \mathrm{CH}_{2}\right), 59.20$ [DTPA amide $\mathrm{NCH}_{2} \mathrm{C}(\mathrm{O})$ ], 54.50 (DTPA central acetate $\mathrm{NCH}_{2} \mathrm{CO}_{2}^{-}$), 59.11 (DTPA terminal acetate $\mathrm{NCH}_{2} \mathrm{CO}_{2}^{-}$), 50.51, 52.89 (DTPA skeleton $\mathrm{NCH}_{2}$ ), 170.51, 173.40, $174.48,178.85$ [DTPA acetate $\mathrm{NCH}_{2} \mathrm{CO}_{2}{ }^{-}$and amide $\mathrm{NCH}_{2} \mathrm{C}(\mathrm{O})$ $\mathrm{NH}$, other $\left.\mathrm{CH}_{2} \mathrm{C}(\mathrm{O}) \mathrm{NH}\right]$ ppm. MS $\left(\mathrm{FAB}^{+}, \mathrm{NBA}\right): \mathrm{m} / z(\%)=1932$ (20) $\left[\mathrm{M}^{+}\right], 1055$ (100). HRMS (FAB $\left.{ }^{+}, \mathrm{NBA}\right)$ : calcd. for $\mathrm{C}_{78} \mathrm{H}_{142} \mathrm{~N}_{13} \mathrm{O}_{34} \mathrm{~S}_{4}[\mathrm{M}+\mathrm{H}]^{+}$1932.8665; found 1932.8576.

Preparation of $\mathbf{L n}^{\mathrm{III}}$ Glycoconjugates for NMR Studies: The $\mathrm{Ln}^{\mathrm{III}}$ glycoconjugates were prepared by adding a slight excess (1.1 equiv.) of $\mathrm{LnCl}_{3}$ aqueous solution to an aqueous solution of the glycoconjugate. The $\mathrm{pH}$ of the solution was slowly adjusted to 5 with $\mathrm{KOH}$ (aq.), stirred at $70{ }^{\circ} \mathrm{C}$ for $8 \mathrm{~h}$ and adjusted to $\mathrm{pH}=7$ with $\mathrm{KOH}$ (aq.). Any precipitate was filtered off. The solution was concentrated and purified by gel filtration with Sephadex G10, eluting with water. The relevant fractions were pooled and freeze-dried to afford the $\mathrm{Ln}^{\mathrm{III}}$ complexes.

Preparation of Gd ${ }^{\mathrm{II}}-\mathrm{DTPALac}{ }_{2}$ for NMRD Measurements: Initially, the DTPALac ${ }_{2}$ conjugate was left to react with an excess of $\mathrm{Gd}\left(\mathrm{ClO}_{4}\right)_{3}$ stock solution and the excess of metal ion was backtitrated with $\mathrm{Na}_{2} \mathrm{H}_{2}$ EDTA solution, allowing the calculation of the exact concentration of glycoconjugate. The Gd ${ }^{\mathrm{III}}$ chelate of DTPA$\mathrm{Lac}_{2}$ was prepared by adding an appropriate quantity of the glycoconjugate to an aqueous solution of gadolinium perchlorate (3-5\% glycoconjugate excess). The solution $\mathrm{pH}$ was slowly adjusted to 7 with $\mathrm{KOH}$ (aq.). The $\mathrm{Gd}^{\mathrm{III}}$ glycoconjugate solution was freezedried and diluted with $25 \mathrm{~mm}$ phosphate buffer $(\mathrm{pH}=7.4)$. The absence of free $\mathrm{Gd}^{\mathrm{III}}$ in the solution was verified by addition of xylenol orange indicator. ${ }^{[30]}$ The $\mathrm{Gd}^{\mathrm{III}}$ concentration $(4.63 \mathrm{mM})$ was verified by ICP measurement.

Supporting Information (see also the footnote on the first page of this article): Table containing the proton relaxivities of $\mathrm{Gd}^{\mathrm{II}}$ DTPALac $_{2}$, and equations for the determination of the relaxivity parameters.

\section{Acknowledgments}

This work was performed within the framework of the EU COST Action D18 "Lanthanide chemistry for diagnosis and therapy".
The work was supported by the Foundation of Science and Technology (F.C.T.), Portugal (project POCTI/QUI/47005/2002) and FEDER. É. T. and A. E. M. acknowledge the Swiss National Science Foundation and the Swiss Federal Office for Education and Science for financial support. The authors are grateful to László Burai for his help with the NMRD measurements.

[1] P. Caravan, J. J. Ellison, T. J. McMurry, R. B. Lauffer, Chem. Rev. 1999, 99, 2293-2352.

[2] É. Tóth, L. Helm, A. E. Merbach, Top. Curr. Chem. 2002, 221, 61-101.

[3] H. J. Weinmann, R. C. Brasch, W. R. Press, G. E. Wesbey, Am. J. Roentgenol. 1984, 142, 619-624.

[4] a) A. D. Watson, J. Alloys Compd. 1994, 207/208, 14-19; b) C. F. G. C. Geraldes, A. M. Urbano, M. C. Alpoim, A. D. Sherry, K.-T. Kuan, R. Rajagopalan, F. Maton, R. N. Muller, Magn. Reson. Imaging 1995, 13, 401-420.

[5] R. C. Brasch, Mag. Reson. Med. 1991, 22, 282-287.

[6] K. P. Aicher, J. W. Dupon, D. L. White, S. L. Aukerman, M. E. Moseley, R. J. Juster, W. Rosenau, J. L. Winkelhace, R. C. Brasch, Cancer Res. 1990, 50, 7376-7381.

[7] S. C. Wang, M. G. Wikstrom, D. L. White, J. Klaveness, E. Holtz, P. Ronved, M. E. Moseley, R. C. Brasch, Radiology 1990, 175, 483-488.

[8] G. Schuhmann-Giampieri, H. Schmitt-Willich, T. Frenzel, W. R. Press, H. J. Weinmann, Invest. Radiol. 1991, 26, 969-974.

[9] E. C. Wiener, S. Konda, A. Shadron, M. Brechbiel, O. Gansow, Invest. Radiol. 1997, 32, 748-754.

[10] S. Aime, M. Fasano, E. Terreno, M. Botta, Protein-Bound Metal Chelates, in The Chemistry of Contrast Agents in Medical Magnetic Resonance Imaging (Eds.: É. Tóth and A. E. Merbach), Wiley, Chichester, 2001, p. 193-241.

[11] R. B. Lauffer, D. J. Parmalee, S. U. Dunham, H. S. Ouellet, R. P. Dolan, S. Witte, T. J. McMurry, R. C. Walowitch, Radiology 1998, 207, 529-538.

[12] F. Cavagna, M. Daprà, F. Maggioni, C. de Haën, E. Felder, Magn. Reson. Med. 1991, 22, 329-333.

[13] H. Schmitt-Willich, M. Brehm, C. L. J. Ewers, G. Mischl, A. Müller-Farnow, O. Petrov, J. Platzek, B. Radüchel, D. Sülzle, Inorg. Chem. 1999, 38, 1134-1144.

[14] G. Kabalka, E. Buonocore, K. Hubner, T. Moss, N. Norley, L. Huang, Radiology 1987, 163, 255-258.

[15] P. H. Weigel, J. H. N. Yik, Biochim. Biophys. Acta (General Subjects) 2002, 1572, 341-363.

[16] a) G. Gregoriadis, Lancet 1981, 2, 241-246; b) D. R. Vera, R. Stadalnik, K. Krohn, J. Nucl. Med. 1985, 26, 1157-1167; c) S. Ishibashi, R. E. Hammer, J. Herz, J. Biol. Chem. 1994, 269, 27 803-27 806; d) K. A. Deal, M. E. Criste, M. J. Welsh, Nucl. Med. Biol. 1998, 25, 379-385.

[17] a) Y. C. Lee, R. R. Townsend, M. R. Hardy, J. Lönngren, J. Arnarp, M. Haraldsson, H. Lönn, J. Biol. Chem. 1983, 258, 199-202; b) R. T. Lee, Y. C. Lee, Biochem. Biophys. Res. Commun. 1988, 155, 1444-1451; c) E. A. L. Biessen, H. Broxterman, J. H. VanBoom, T. J. VanBerkel, J. Med. Chem. 1995, 38, $1846-1852$.

[18] S. D. Colquhoum, C. A. Conelly, D. R. Vera, J. Nucl. Med. 2001, 42, 110-116.

[19] K. Miki, K. Kubota, Y. Inoue, D. R. Vera, M. Makuuchi, J. Nucl. Med. 2001, 42, 733-737.

[20] N. Shuke, H. O. Kizaki, S. Kino, J. Sato, Y. Ishikawa, C. L. Zhao, S. Kineya, N. Watabane, K. Yokoama, T. Aburano, J. Nucl. Med. 2003, 44, 475-482.

[21] B. K. Schaffer, C. Linker, M. Papisov, E. Tsai, N. Nossiff, T. Shibata, A. Bogdanov, T. J. Brady, R. Weissleder, Magn. Reson. Imaging 1993, 11, 411-417.

[22] P. Reimer, R. Weissleder, A. S. Lee, S. Buettner, J. Wittenberg, T. J. Brady, Radiology 1991, 178, 769-774.

[23] P. Reimer, R. Weissleder, T. J. Brady, Radiology 1992, 182, $1161-1167$. 
[24] B. Gallez, V. Lacour, R. Demeure, R. Debuyst, F. Dejehet, J. L. Dekeyser, P. Dumont, Magn. Reson. Imag. 1994, 12, 61-69.

[25] D. R. Vera, M. H. Buonocore, E. R. Wisner, R. W. Katzberg, R. C. Stadalnik, Acad. Radiol. 1995, 2, 497-506.

[26] J. P. André, C. F. G. C. Geraldes, J. A. Martins, A. E. Merbach, M. I. M. Prata, A. C. Santos, J. J. P. de Lima, É. Tóth, Chem. Eur. J. 2004, 10, 5804-5816.

[27] M. M. Alauddin, A. Y. Louie, A. Shahinian, T. J. Meade, P. S. Conti, Nucl. Med. Biol. 2003, 30, $261-265$.

[28] R. A. Moats, S. E. Fraser, T. J. Meade, Angew. Chem. Int. Ed. Engl. 1997, 36, 726-728.

[29] a) M. Elofsson, B. Walse, J. Kihlberg, Tetrahedron Lett. 1991, 32, 7613-7616; b) M. Elofsson, S. Roy, B. Walse, J. Kihlberg, Carbohydr. Res. 1993, 246, 89-103; c) M. J. Kiefel, R. J. Thomson, M. Radovanovik, M. V. Itzstein, J. Carbohydr. Chem. 1999, 18, 937-959.

[30] G. Brunisholtz, M. Randin, Helv. Chim. Acta 1959, 42, $1927-$ 1938.

[31] D. Zanini, R. Roy, J. Org. Chem. 1996, 61, 7348-7354.

[32] G. R. Choppin, P. A. Baisden, S. A. Khan, Inorg. Chem. 1979, 18, 1330-1332.

[33] S. Aime, M. Botta, Inorg. Chim. Acta 1990, 177, 101-105.

[34] E. N. Rizkalla, G. R. Choppin, W. Cacheris, Inorg. Chem. 1993, $32,582-586$.

[35] C. F. G. C. Geraldes, R. Delgado, A. M. Urbano, J. Costa, F. Janasada, F. Nepveu, J. Chem. Soc., Dalton Trans. 1995, 327335.

[36] J. A. Peters, E. Z.-Bovens, D. Corsi, C. F. G. C. Geraldes, Structure and Dynamics of Gadolinium Based Contrast Agents, in The Chemistry of Contrast Agents in Medical Magnetic Resonance Imaging (Eds.: É. Tóth, A. E. Merbach), Wiley, Chichester, 2001, p. 315-381.
[37] B. M. Alsaadi, F. J. C. Rossotti, R. J. P. Williams, J. Chem. Soc., Dalton Trans. 1980, 2151-2154.

[38] J. A. Peters, Inorg. Chem. 1988, 27, 4686-4691.

[39] a) B. J. Jenkins, R. B. Lauffer, J. Magn. Reson. 1988, 80, 328 336; b) B. J. Jenkins, R. B. Lauffer., Inorg. Chem. 1988, 27, 4730-4738.

[40] C. F. G. C. Geraldes, A. M. Urbano, M. A. Hoefnagel, J. A. Peters, Inorg. Chem. 1993, 32, 2426-2432.

[41] H. Lammers, F. Maton, D. Pubanz, M. W. van Laren, H. van Bekkum, A. E. Merbach R. N. Muller, J. A. Peters, Inorg. Chem. 1997, 36, 2527-2538.

[42] K. Kimpe, T. Parac-Vogt, S. Laurent, C. Piérart, L. Vander Elst, R. N. Muller, K. Binnemans, Eur. J. Inorg. Chem. 2003, 3021-3027.

[43] É. Tóth, L. Helm, A. E. Merbach, Relaxivity of Gadolinium(iii) Complexes: Theory and Mechanism, in The Chemistry of Contrast Agents in Medical Magnetic Resonance Imaging (Eds.: É. Tóth, A. E. Merbach), Wiley, Chichester, 2001, p. 45119.

[44] D. H. Powell, O. M. Ni Dhubhghaill, D. Pubanz, L. Helm, Y. S. Lebedev, W. Schlaepfer, A. E. Merbach, J. Am. Chem. Soc. 1996, 118, 9333-9346.

[45] a) A. D. McLachlan, Proc. R. Soc. London, A 1964, 280, 271; b) D. H. Powell, A. E. Merbach, G. González, E. Brücher, K. Micskei, M. F. Ottaviani, K. Köhler, A. von Zelewsky, O. Y. Grinberg, Y. S. Lebedev, Helv. Chim. Acta 1993, 76, 2129-2146.

[46] a) S. Rast, A. Borel, L. Helm, E. Belorizky, P. H. Fries, A. E. Merbach, J. Am. Chem. Soc. 2001, 123, 2637-2644; b) S. Rast, P. H. Fries, E. Belorizky, A. Borel, L. Helm, A. E. Merbach, J. Chem. Phys. 2001, 115, 7554-7563.

Received: September 15, 2004 